\title{
Anestesi untuk Kraniotomi Evakuasi Perdarahan Intraserebral pada Pasien Cedera Otak Traumatik dengan Tetralogy of Fallot
}

\author{
Dhania A Santosa, Hamzah Hamzah \\ Departemen Anestesiologi \& Reanimasi Fakultas Kedokteran Universitas Airlangga-RSUD dr. Soetomo Surabaya
}

\begin{abstract}
Abstrak
Penyakit jantung bawaan (PJB) merupakan salah satu penyakit bawaan yang paling sering terjadi, yaitu sekitar 8 dari 1000 kelahiran hidup. Sekitar 85\% dari pasien dengan PJB diharapkan bertahan hidup sampai dengan usia dewasa di Amerika Serikat. Penanganan cedera otak traumatik dengan PJB memerlukan pemahaman patofisiologi PJB dengan teknik neuroanestesi yang baik. Seorang laki-laki usia 17 tahun mengalami kecelakaan lalu lintas dan didiagnosis dengan cedera otak traumatik sedang, perdarahan intraserebral (ICH) dan perdarahan epidural (EDH) serta edema serebri dengan komorbiditas PJB sianotik Tetralogy of Fallot, dilakukan pembedahan darurat kraniotomi evakuasi ICH. Pembedahan dilakukan dengan anestesi umum intubasi endotrakeal dan berjalan selama kurang lebih tiga jam. Tantangan selama anestesi dan pembedahan adalah mempertahankan hantaran oksigen optimal, menghindari peningkatan kebutuhan oksigen dan mencegah pelepasan katekolamin yang dapat memicu terjadinya hypercyanotic tet spell. Pascabedah pasien dirawat di Ruang Observasi Intensif dengan bantuan ventilator dan dilakukan ekstubasi pada sore hari pertama pascabedah. Pasien kemudian dirawat di Ruangan dan dipulangkan pada hari ke-14 pascabedah.
\end{abstract}

Kata kunci: Anestesi, cedera otak traumatika, Tetralogy of Fallot

JNI 2020, 9 (3): 156-67

\section{Anesthesia Management for Craniotomy for Intracerebral Hemorrhage Evacuation in Traumatic Brain Injury Patient with Tetralogy of Fallot}

\begin{abstract}
Congenital heart disease (CHD) is one of the leading congenital disease with the incidence of 8 patients of 1000 livebirth. Around 85\% of patients with CHD is expected to reach adult age in United States of America. Management of traumatic brain injury in patients with CHD requires combination of fine understanding on pathophysiology of CHD and neuroanesthesia technique. A male patient, 17 years of age had a motor vehicle accident and was diagnosed with moderate traumatic brain injury, intracerebral hemorrhage, epidural hemorrhage and cerebral edema with Tetralogy of Fallot, underwent an emergency craniotomy for ICH evacuation. Surgery was done under general anesthesia and lasted for approximately 3 hours. Challenges during anesthesia and surgery include maintaining optimal oxygen delivery, avoiding increase in oxygen demand and preventing catecholamine release which may trigger hypercyanotic tet spell. Patient was observed and ventilator supported in Intensive Observation Ward and was extubated at the same post surgery day. Patient was then observed in the Ward and sent home on the 14th day after the incident.
\end{abstract}

Key words: anesthesia management, traumatic brain injury, Tetralogy of Fallot

JNI 2020, 9 (3): 156-67

This article is licensed under a

Creative Commons Attribution-NonCommercial-ShareAlike 4.0 International License.

CDhania A. Santoso, Hamzah (2020) under the CC-BY-NC-SA license 


\section{Pendahuluan}

Penyakit Jantung Bawaan (PJB) merupakan kelainan bawaan yang paling sering terjadi, dengan angka kejadian sekitar 8 dari 1000 kelahiran hidup. ${ }^{1}$ Sekitar $85 \%$ dari seluruh pasien PJB diharapkan untuk bertahan hidup sampai dengan usia dewasa di Amerika Serikat. ${ }^{2}$ Sekitar 25\% pasien mengalami PJB dalam bentuk ringan sehingga pasien-pasien ini dapat bertahan sampai dengan dewasa tanpa pembedahan atau intervensi kateterisasi jantung. ${ }^{3}$ Jumlah pasien dewasa dengan penyakit jantung bawaan (PJB) semakin meningkat dan sebagai akibatnya maka jumlah pasien dengan PJB yang menjalani pembedahan non-jantung juga akan meningkat. Adanya PJB meningkatkan mortalitas dan morbiditas pada pasien yang menjalani pembedahan non jantung secara signifikan, dengan mortalitas 30 hari pada pasien dengan kelainan jantung mayor dua kali lebih besar dibandingkan pasien dengan kelainan jantung minor. ${ }^{4}$ Anatomi dan fisiologi PJB sangatlah rumit dan memerlukan pengetahuan spesifik mengenai defek dan implikasi anestesinya. ${ }^{3}$

Tetralogy of Fallot (TOF) merupakan penyebab PJB sianotik terbanyak pada anak, yakni sekitar $10 \%$ dari seluruh angka kejadian $\mathrm{PJB}^{2}$ Tujuh puluh persen pasien dengan TOF akan meninggal sebelum usia 10 tahun bila tidak dikoreksi, meskipun dapat juga bertahan sampai dengan masa dewasa. ${ }^{5}$ Pasien dengan PJB, terutama defek yang kompleks (TOF di antaranya), meningkatkan morbiditas perioperatif. ${ }^{6}$ Faktor risiko tambahan untuk terjadinya luaran yang buruk pada pembedahan non jantung adalah sifat operasi darurat dan prosedur yang melibatkan pernapasan dan sistem saraf pusat. ${ }^{6}$ Pada pasien ini terdapat semua faktor tersebut sehingga anestesi dan pembedahan pada pasien ini sangat tinggi risiko morbiditas dan mortalitasnya. Keberhasilan penanganan pasien cedera otak traumatika dengan PJB sianotik memerlukan pemahaman patofisiologi yang baik akan PJB yang dialami pasien dan teknik neuroanestesi sehingga hantaran oksigen ke otak tetap terjaga dan menghindari terjadinya cedera otak sekunder.

\section{Kasus}

Seorang laki-laki berusia 17 tahun, berat badan $50 \mathrm{~kg}$ dengan cedera otak sedang, perdarahan intraserebral (ICH) parietal kiri, Tetralogy of Fallot, dilakukan kraniotomi dan evakuasi ICH.

\section{Anamnesis}

Pasien mengalami kecelakaan lalu lintas 3 jam sebelum tiba di RSUD Dr. Soetomo Surabaya. Pasien terjatuh saat dibonceng sepeda motor, kepala membentur aspal dan pasien tidak memakai helm. Pasien pingsan dan muntah 2 kali serta keluar darah dari telinga.

\section{Pemeriksaan Fisik}

Pada saat dilakukan survei primer di Ruang Resusitasi RSUD Dr. Soetomo Surabaya, ditemukan pasien dengan kondisi jalan napas bebas, dengan pernapasan spontan 20 kali per menit, gerak dada simetris dan tidak ada jejas di dada. Suara napas vesikuler kanan dan kiri, tidak terdapat suara napas tambahan. Pulse oximetry terbaca $76 \%$ dengan $\mathrm{O}_{2}$ udara bebas $\left(\mathrm{FiO}_{2} 21 \%\right)$. Pada perabaan didapatkan perfusi hangat, kering dan sianotik, dengan capillary refill time kurang dari 2 detik. Tekanan darah 130/80 mmHg dan MAP (Mean Arterial Pressure) $97 \mathrm{mmHg}$ dan nadi 88 kali per menit, nadi radialis teraba teratur dan kuat angkat. Kesadaran response to pain.

Tindakan yang dilakukan seiring dengan survei primer di antaranya, mempertahankan jalan napas tetap bebas dan menjaga posisi leher tetap in-line, diberikan suplemen $\mathrm{O}_{2}$ dengan masker reservoir 8 liter per menit dengan waspada terhadap tandatanda tension pneumothorax. Dipasang sebuah akses intravena dengan diberikan cairan $\mathrm{NaCl}$ 0,9\% $50 \mathrm{~mL} / \mathrm{jam}$. Kemudian dilakukan log roll untukmengevaluasijejas ditubuhbagianbelakang, posisi leher dipertahankan in-line. Dilakukan pemasangan kateter urin dan pengambilan sampel darah. Pada survei sekunder didapatkan GCS E2V2M5 dengan pupil bulat isokor $4 \mathrm{~mm}$ mata kanan dan kiri serta refleks cahaya positif. Selain itu pasien dengan jalan napas bebas tanpa tanda distress napas dengan suara napas vesikuler kanan dan kiri tanpa suara napas tambahan. 
Dengan $\mathrm{O}_{2}$ non-rebreathing mask 10 liter per menit terbaca pulse oximetry 86\%. Tekanan darah 120/90 dan MAP $100 \mathrm{mmHg}$, nadi 68 kali per menit, dengan perfusi hangat kering sianotik dan didapatkan clubbing finger serta vulnus ekskoriasi di regio antebrachii kiri. Temuan survei sekunder lainnya dalam batas normal. Dari heteroanamnesis ibu pasien didapatkan riwayat penyakit jantung bawaan sejak lahir yang belum pernah mendapatkan terapi apa pun baik operatif maupun medikamentosa. Dari pemeriksaan foto toraks didapatkan paru

\section{Pemeriksaan Penunjang}

Tabel 1. Hasil Pemeriksaan Laboratorium Pra Bedah

\begin{tabular}{ll}
\hline Hemoglobin & $20,5 \mathrm{~g} / \mathrm{dL}$ \\
Hematokrit & $58,5 \%$ \\
Leukosit & $15.620 / \mathrm{mm} 3$ \\
Trombosit & $176.000 \mu / \mathrm{L}, \mathrm{L}$ \\
PPT (kontrol) & $14,9(10,9)$ \\
aPTT (kontrol) & $31,7(26,3)$ \\
Natrium & $144 \mathrm{mEq} / \mathrm{L}$ \\
Kalium & $4,1 \mathrm{mEq} / \mathrm{L}$ \\
Chlorida & $111 \mathrm{mEq} / \mathrm{L}$ \\
Gula darah acak & $149 \mathrm{mg} / \mathrm{dL}$ \\
$\mathrm{BUN}_{\mathrm{Kreatinin}}$ serum & $11 \mathrm{mg} / \mathrm{dL}$ \\
$\mathrm{SGOT}_{\mathrm{SGPT}}$ & $47 \mu \mathrm{mg} / \mathrm{dL}$ \\
$\mathrm{Analisa}$ gas darah & $\mathrm{O} 2 \mathrm{non} \mathrm{rebreathing} \mathrm{mask} 10$ \\
& $1 \mathrm{pm}$ \\
$\mathrm{pH}_{\mathrm{pCO}}$ & 7,45 \\
$\mathrm{pO}_{2}$ & 28,1 \\
$\mathrm{HCO}_{3}$ & 53,7 \\
$\mathrm{BE}_{\mathrm{SaO}}$ & 19,7 \\
\hline
\end{tabular}

dalam batas normal dengan Cardio Thoracic Ratio (CTR) 49\%, tidak didapatkan hematotoraks maupun pneumotoraks. Dari foto cervical posisi lateral didapatkan cervical in line, tulang-tulang dalam batas normal. Dari pemeriksaan CT scan kepala didapatkan scalp hematoma di parietal dan occipital kiri, perdarahan intraserebral (ICH) di parietal kiri dengan volume kurang lebih 28 $\mathrm{ml}$, perdarahan epidural (EDH) occipital kiri dengan tebal $1,05 \mathrm{~cm}$. Selain itu didapatkan pergeseran garis tengah $0,4 \mathrm{~cm}$ dan edema serebri. Dari pemeriksaan elektrokardiografi didapatkan

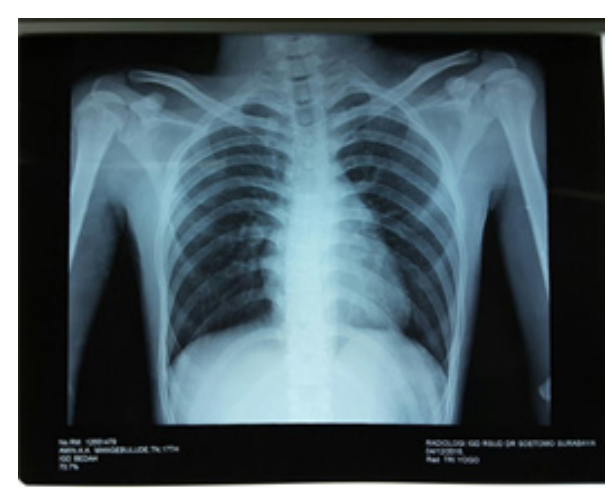

Gambar 1. Foto Toraks Pasien dalam Batas Normal

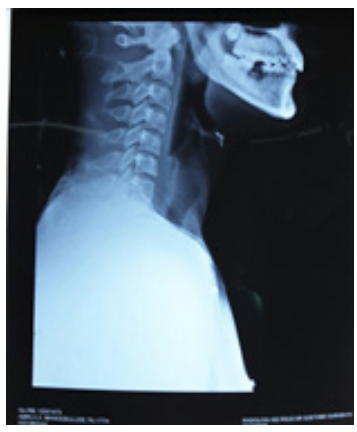

Gambar 2. Foto Cervical Lateral Pasien dalam Batas Normal

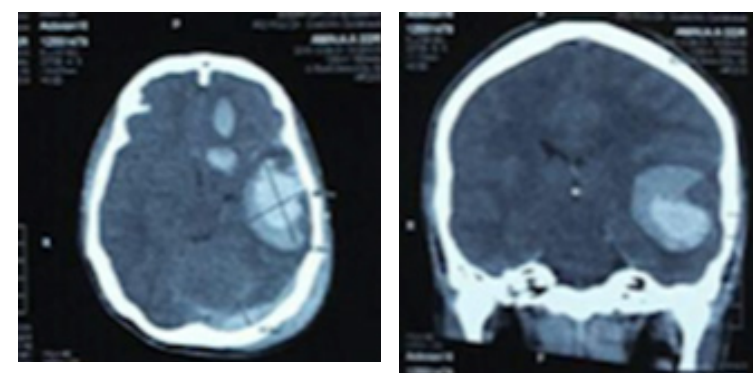

Gambar 3. CT Scan Kepala pasien menunjukkan scalp hematoma, ICH dan EDH, pergeseran garis tengah serta edema serebri

irama sinus, dengan frekuensi jantung 90 kali per menit. Pada pasien ini dilakukan pemeriksaan ekokardiografi dan didapatkan hasil hipertrofi 
ventrikel kanan, pulmonary stenosis (PS) ringan, pulmonary regurgitation (PR) ringan, dengan septum atrium intak dan septum ventrikel terdapat ventricular septal defect (VSD) perimembranous $(1,1-1,2 \mathrm{~cm})$, dengan ejection fraction ventrikel kiri $75 \%$, terdapat aliran pada arteri pulmonal dan VSD. Pasien disimpulkan dengan Tetralogy of Fallot (TOF) dengan McGoon ratio 2,2.

\section{Pengelolaan Anestesi}

Dalam observasi dan persiapan pembedahan, pasien diberikan total cairan $\mathrm{NaCl} 0,9 \% 500 \mathrm{~mL}$ dengan total produksi urine sebanyak $400 \mathrm{~mL}$ dalam waktu 5 jam sejak pasien datang sampai dengan pasien tiba di kamar operasi. Kondisi pasien pada saat akan dilakukan induksi anestesi adalah sebagai berikut: jalan napas bebas dengan pernapasan spontan 28 kali per menit tanpa tanda distress napas. Pulse oximetry terbaca $89 \%$ dengan $\mathrm{O}_{2}$ masker non-rebreathing mask $81 \mathrm{pm}$. Perfusi hangat kering sianotik dengan tekanan darah 100/70 $\mathrm{mmHg}$ dan MAP $80 \mathrm{mmHg}$ dan nadi 70 kali per menit, teraba reguler dan kuat angkat pada arteri radialis. Suhu timpanik pasien $36,7^{\circ} \mathrm{C}$. Kesadaran dengan skor GCS E2V2M5, pupil bulat isokor mata kanan kiri diameter $4 \mathrm{~mm}$ dengan refleks cahaya positif. Produksi urine 80 $\mathrm{mL} / \mathrm{jam}$, warna kuning jernih.

Pasien kemudian dilakukan induksi dengan obatobatan anestesi sebagai berikut: fentanyl 200 $\mathrm{mcg}$, thiopental $100 \mathrm{mg}$ kemudian ditambahkan lagi $50 \mathrm{mg}$ dan rocuronium $40 \mathrm{mg}$. Intubasi dilakukan dengan pipa endotrakeal no. 7,5, simetris dan dilakukan fiksasi pada $20 \mathrm{~cm}$ di tepi bibir. Kemudian dipasang kateter vena sentral pada vena subclavia kanan. Selama pembedahan dilakukan dengan rumatan anestesi inhalasi isoflurane, $\mathrm{O}_{2}$ dan air, kontrol ventilasi dengan $\mathrm{FiO}_{2}$ 80-100\%, dengan fentanyl dan rocuronium diberikan secara kontinu. Selain itu selama anestesi dan pembedahan diberikan norepinephrine secara kontinu. Hasil analisa gas darah selama pembedahan $\mathrm{pH} 7,38 ; \mathrm{pCO}_{2} 35,6$; $\mathrm{pO}_{2}$ 59,9; $\mathrm{HCO}_{3} 21,4 ; \mathrm{BE}-3,8 ; \mathrm{SaO}_{2} 90,3 \%$.

Selama pembedahan ditemukan duramater tegang dengan warna kebiruan di daerah temporal, hematoma intrakranial dengan volume sekitar 50
$\mathrm{mL}$, otak bulging dan terdapat laserasi serebri di daerah temporal dan parietal. Dilakukan evakuasi hematoma dan tulang kepala tidak dikembalikan. Selama pembedahan, tekanan darah berkisar 88124/54-74 mmHg dan MAP berkisar antara $65-$ $91 \mathrm{mmHg}$. Nadi berkisar antara 70-105 kali per menit. Suhu pasien selama pembedahan 36,5 $36,7^{\circ} \mathrm{C}$ dengan pulse oximetry $82-92 \%$. End tidal $\mathrm{CO}_{2}\left(\mathrm{ETCO}_{2}\right)$ berkisar antara 33-35.

Keseimbangan cairan selama pembedahan

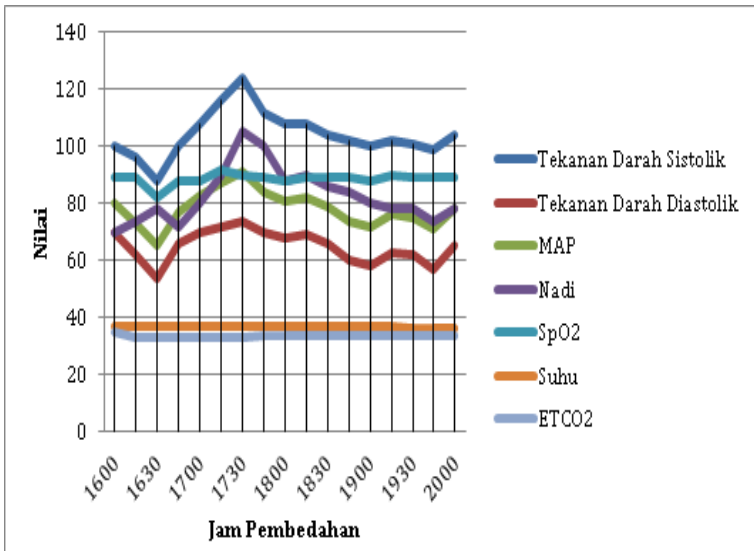

Gambar 4. Kondisi Pasien selama Pembedahan

yaitu input $\mathrm{NaCl} 0,9 \% 500 \mathrm{~mL}$ dan whole blood $350 \mathrm{~mL}$. Produksi urin $600 \mathrm{~mL}$ dan estimasi perdarahan $200 \mathrm{~mL}$.

\section{Pascabedah}

Pascabedah pasien diobservasi di Ruang Observasi Intensif (ROI) dengan kondisi jalan napas bebas dengan pipa endotrakeal dengan bantuan ventilator PCV rate 15 PC 8 Trigger 2 I:E 1:2 PEEP $6 \mathrm{FiO}_{2} 80 \%$ dengan luaran rate 15 kali per menit, volume tidal $470-476 \mathrm{~mL}$, ventilasi semenit $7,0-7,1, \mathrm{SpO}_{2} 89 \%$, suara napas vesikuler pada kedua lapang paru tanpa suara napas tambahan. Perfusi hangat kering sianotik dengan tekanan darah 114/63 $\mathrm{mmHg}$, MAP 80 mmHg. Nadi 82 kali per menit, CVP 5-8 $\mathrm{cmH}_{2} \mathrm{O}$, suhu timpanik $36,7^{\circ} \mathrm{C}$. Kesadaran masih dalam pengaruh obat anestesi. Produksi urine $30 \mathrm{~mL} /$ jam warna kuning jernih. Diberikan terapi di antaranya posisi head up elevasi $30^{\circ} \mathrm{C}, \mathrm{NaCl}$ 0,9\% $1000 \mathrm{~mL} / 24$ jam, injeksi Ceftriaxone 2 
x 1 gram iv, ranitidine 2 x $50 \mathrm{mg}$ iv, fenitoin $3 \times 100 \mathrm{mg}$ iv, mannitol $6 \times 100 \mathrm{~mL}$ serta fentanyl kontinu $25 \mathrm{mcg} / \mathrm{jam}$ iv.

Tabel 2. Hasil Pemeriksaan Laboratorium Pascabedah

\begin{tabular}{ll}
\hline Hemoglobin & $14,4 \mathrm{~g} / \mathrm{dL}$ \\
Hematokrit & $42,2 \%$ \\
Leukosit & $10.930 / \mathrm{mm} 3$ \\
Trombosit & $124.000 \mu / \mathrm{L}, \mathrm{L}$ \\
Natrium & $146,5 \mathrm{mEq} / \mathrm{L}$ \\
Kalium & $3,21 \mathrm{mEq} / \mathrm{L}$ \\
Chlorida & $112,2 \mathrm{mEq} / \mathrm{L}$ \\
Gula darah acak & $94 \mathrm{mg} / \mathrm{dL}$ \\
Albumin & $2,85 \mathrm{~g} / \mathrm{dL}$ \\
Analisa gas darah & \\
$\mathrm{pH}$ & 7,45 \\
$\mathrm{pCO}_{2}$ & 39,2 \\
$\mathrm{pO}_{2}$ & 49 \\
$\mathrm{HCO}_{3}$ & 25 \\
$\mathrm{BE}$ & 0,1 \\
$\mathrm{SaO}_{2}$ & $85 \%$ \\
\hline
\end{tabular}

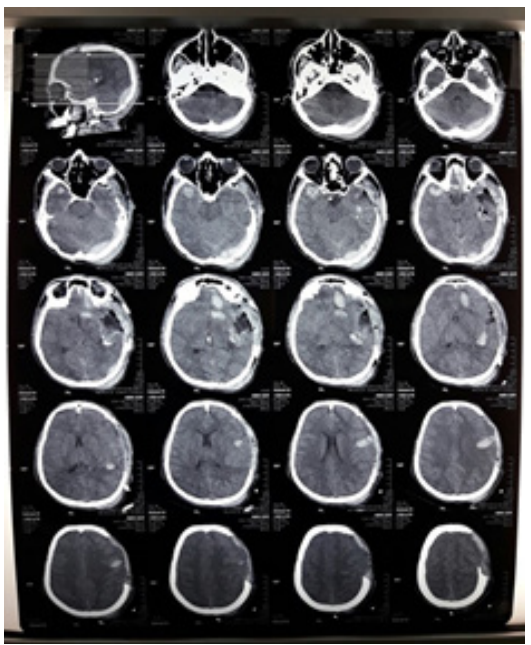

Gambar 5. CT Scan Kepala Pascabedah

Dilakukan CT scan kepala pascabedah, pasien kemudian disapih dari ventilator dan dilakukan ekstubasi.

Pada hari pertama pascabedah, kondisi pasien adalah sebagai berikut: jalan napas bebas dengan

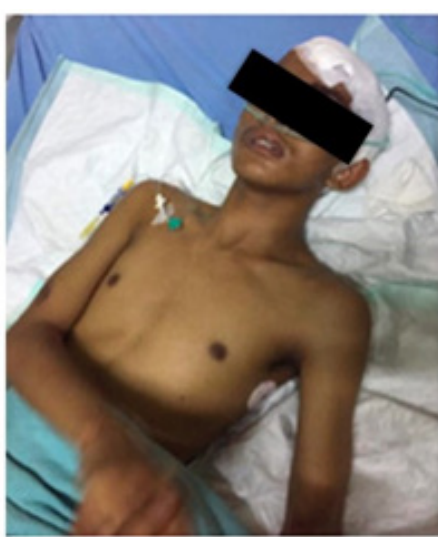

Gambar 5. CT Scan Kepala Pascabedah

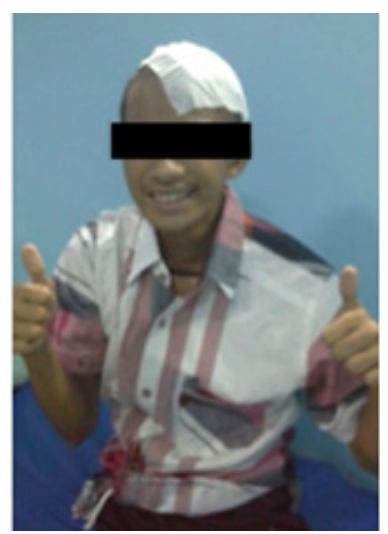

Gambar7.Kondisi Pasien saat Kontrol ke Instalasi Rrawat Jalan pada hari ke-21 pascabedah

pernapasan spontan 16 kali per menit, suara nafas vesikuler kedua lapang paru tanpa suara napas tambahan, pulse oximetry terbaca $80 \%$ dengan suplementasi $\mathrm{O}_{2}$ nasal canule $2 \mathrm{lpm}$. Tekanan darah 124/71 mmHg dengan MAP $89 \mathrm{mmHg}$. Nadi 86 kali per menit, teraba reguler dan kuat angkat pada arteri radialis. Suhu timpanik $36,8^{\circ} \mathrm{C}$. Kondisi kesadaran pasien dengan GCS E3 V3 M6 dengan pupil bulat isokor $3 \mathrm{~mm}$ mata kanan dan kiri dan refleks cahaya positif. Produksi urine 25 $\mathrm{mL}$ per jam dengan warna kuning jernih.

Pasien kemudian dipindahkan ke ruangan pada sore hari pertama pascabedah dengan kondisi jalan napas bebas, pernapasan spontan 20 kali per menit dengan pulse oximetry $81 \%$ dengan $\mathrm{O}_{2}$ nasal canule $2 \mathrm{lpm}$. Tekanan darah 140/80 $\mathrm{mmHg}$, MAP $100 \mathrm{mmHg}$, nadi 80 kali per menit. Kondisi kesadaran dengan GCS E3 V4 M6. Pasien dipulangkan pada hari ke-14 pascabedah 
dengan kondisi kesadaran GCS E4 V5 M6.

\section{Pembahasan}

Seorang laki-laki berusia 17 tahun, berat badan $50 \mathrm{~kg}$ mengalami kecelakaan sepeda motor di mana pasien tidak mengenakan helm dan jatuh dengan kepala membentur aspal. Pasien kemudian didiagnosis dengan cedera otak sedang, perdarahan intraserebral (ICH) parietal kiri, Tetralogy of Fallot (TOF), dilakukan kraniotomi dan evakuasi ICH. Pengelolaan pasien ini memerlukan ahli anestesi yang memahami tidak hanya teknik neuroanestesi namun juga fisiologi dan implikasi dari kelainan jantung bawaan dalam hal ini adalah TOF. Dengan mengantisipasi masalah pada populasi pasien ini maka risiko perioperatif dapat dikurangi.

TOF merupakan suatu penyakit jantung bawaan dengan kelainan anatomi jantung di antaranya adalah stenosis pulmonal, hipertrofi ventrikel kanan, overriding aorta dan ventricular septal defect (VSD). Meskipun terdiri dari empat defek, TOF sebenarnya merupakan spektrum penyakit, mulai dari pasien dengan VSD, overriding aorta dan stenosis pulmonal ringan sampai dengan pasien dengan VSD dan atresia pulmonal. Pasien dengan TOF umumnya tampak sianosis. Hal ini disebabkan karena adanya obstruksi jalur keluar dari ventrikel kanan menuju ke arteri pulmonalis, sehingga darah dari ventrikel kanan yang belum teroksigenasi akan mengalir ke dalam ventrikel kiri dan kemudian dipompa ke seluruh tubuh. Berbeda dengan pasien dengan VSD besar murni di mana jalur keluar dari ventrikel kanan ke arteri pulmonalis tidak mengalami hambatan. Pasienpasien dengan VSD besar murni justru berisiko mengalami penyakit pembuluh darah paru akibat besarnya tekanan yang diterima pembuluh darah paru terkait banyaknya volume darah yang masuk ke arteri pulmonalis. ${ }^{2}$

Pada pasien TOF yang tidak dikoreksi, patofisiologi yang terjadi bergantung pada derajat obstruksi jalur keluar ventrikel kanan (Right Ventricle Outflow Tract $\neg$ RVOT). Dengan obstruksi RVOT yang signifikan, maka sedikit sekali aliran darah pada arteri pulmonal sehingga

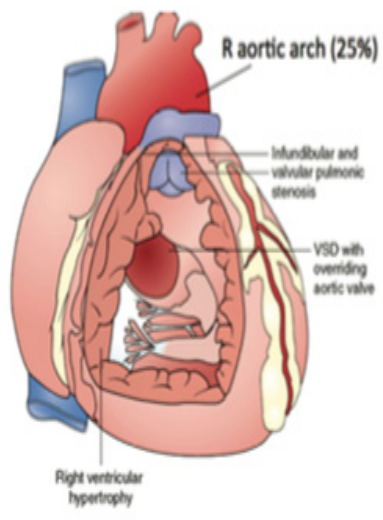

Source: Andropoulos and Gottlieb; Congental Heart Diseose, Anesthesia and Uncommon Diseases, 6eh Ed, Flesher L. (ed.) 2012, p. 111.

\section{Gambar 8. Anatomi Tetralogy of Fallot}

memaksa darah dari kanan ke kiri melalui VSD dan menyebabkan desaturasi arteri yang signifikan.

Hypercyanotic Tet Spell terjadi akibat dari pelepasan katekolamin karena nyeri, stress, anestesia dangkal dan kemarahan pada bayi atau anak. Banyak pasien dengan TOF mendapatkan propranolol oral untuk mencegah spell ini. Pada saat terjadi spell, pasien dengan TOF dapat melakukan posisi jongkok untuk meningkatkan tahanan pembuluh darah sistemik, menurunkan aliran darah kanan ke kiri dan meningkatkan aliran darah pulmonal, yang dapat meringankan sianosis. ${ }^{3}$ Apabila spell terjadi selama anestesi dan pembedahan, terapi yang dapat diberikan di antaranya pemberian volume intravaskular untuk meningkatkan stroke volume ventrikel kanan, meningkatkan sedasi atau analgesia, menghindari katekolamin eksogen, meningkatkan $\mathrm{FiO}_{2}$ dan meningkatkan resistensi vaskular sistemik untuk memaksa darah dari kiri ke kanan melalui VSD dan keluar dari RVOT, ${ }^{4}$ sehingga meningkatkan aliran darah paru dan pada akhirnya meningkatkan oksigenasi. Pasien TOF tidak dikoreksi yang menginjak usia remaja atau dewasa mungkin mengalami dilatasi ventrikel kanan dan rentan mengalami aritmia ventrikel. ${ }^{7}$

Risiko terjadinya komplikasi jantung selama pembedahan non jantung harus dinilai berdasarkan jenis pembedahannya dan kegawatan penyakit jantung dasarnya. ${ }^{8}$ Pasien dengan PJB, 
terutama dengan defek yang kompleks, akan meningkatkan morbiditas perioperatif. Pada pasien dewasa dengan PJB harus digali riwayat pembedahan sebelumnya dan prosedur yang dilakukan, ada atau tidaknya lesi jantung yang tersisa, komplikasi penyakit jantung dan kondisi saat ini. Tabel 3 menunjukkan faktor risiko yang umum didapatkan pada pasien dewasa dengan PJB.

PJB sianotik termasuk di antaranya defek jantung anatomis menyebabkan berkurangnya aliran darah paru atau sebagai akibat dari percampuran darah yang teroksigenasi dan darah yang terdeoksigenasi. Kedua kondisi ini menyebabkan berkurangnya isian oksigen dalam darah dan terjadi sianosis. Salah satu defek yang paling sering terlihat pada PJB dewasa di antaranya adalah TOF. Permasalahan yang harus diantisipasi pada PJB sianotik di antaranya adalah hipoksemia, polisitemia, pencegahan gangguan organ, abses otak dan endokarditis, ${ }^{8}$ di mana semuanya ini, baik langsung maupun tidak, terkait dengan kondisi otak pasien. Selain itu, pasien sianosis juga memiliki risiko tinggi untuk terjadi perdarahan dan trombosis perioperatif, sekalipun pada pembedahan minor. ${ }^{3}$

Dalam kondisi sianosis, tubuh akan mengalami eritrositosis sekunder sebagai respons kompensasi terhadap hipoksia kronis dan terjadi karena produksi berlebih eritropoietin. Hal ini menyebabkan peningkatan viskositas darah keseluruhan karena peningkatan massa sel darah merah dan penurunan volume plasma. Hasil akhirnya adalah penurunan aliran darah pada arteriol kecil dan kapiler, termasuk aliran darah otak sehingga otak dalam kondisi hipoksia kronis. Hal ini dapat menimbulkan gejala hiperviskositas di antaranya nyeri kepala, pingsan, pusing, kelelahan, perubahan kesadaran, gangguan penglihatan, parestesi, tinnitus dan myalgia. ${ }^{9}$ Hal ini akan diperparah dengan kondisi dehidrasi dan defisiensi besi. Sel darah

Tabel 3. Faktor Risiko Jantung pada Pasien Dewasa dengan PJB

\begin{tabular}{ll}
\hline Faktor Risiko Berat & Hipertensi pulmonal berat, termasuk Sindroma Eisenmenger \\
& Lesi menetap signifikan setelah pembedahan perbaikan (reparative) (contoh: \\
& pasien diindikasikan untuk menjalani pembedahan ulang atau kateterisasi) \\
& Gagal jantung dekompensasi, Kelas III atau IV NYHA \\
& Disfungsi ventrikel sistemik berat, EF < 35\% \\
& Hipoksemia berat (penyakit jantung sianotik yang tidak diterapi, setelah pem- \\
& bedahan paliatif) \\
& Aritmia hebat (aritmia yang tidak berespon terhadap terapi obat, dan yang \\
& diindikasikan untuk kateterisasi atau pacing) \\
& lesi menetap sedang setelah pembedahan perbaikan (reparative) \\
& gagal jantung terkompensasi \\
Faktor Risiko Sedang & setelah pembedahan Fontan \\
& setelah pembedahan paliatif (terdapat hipoksemia) \\
& penyakit jantung bawaan tidak memerlukan perbaikan \\
& pasien sudah menjalani perbaikan jantung di mana terapi lanjutan tidak diper- \\
Faktor Risiko Ringan & lukan \\
& aritmia yang sedang diterapi dengan obat oral
\end{tabular}

Dikutip dari: Warnes CA, Williams RG, Bashore TM, Child JS, Connolly HM, Dearani JA, dkk. ACC/AHA 2008 Gudielines for the Management of Adults with Congenital Heart Disease: A Report of the American College of Cardiology/ American Heart Association Task Force on Practice Guidelines (Writing Committee to Develop Guidelines on the Management of Adults with Congenital Heart Disease): Developed in Collaboration with the American Society of Echocardiography, Heart Rhythm Society, International Socitey for Adult Congenital Heart Disease, Society for Cardiovascular Angiography and Interventions, and Society of Thoracic Surgeons. Circulation 2008;118:e714-e833 
merah yang kurang besi kehilangan kemampuan untuk berubah bentuk dan hal ini merupakan salah satu prediktor independen terkuat untuk terjadinya trombosis, dan pada akhirnya akan menyebabkan terjadinya infark pada otak, ginjal dan paru. Pada pasien dengan perfusi paru yang terbatas, perlu dihindari terjadinya dehidrasi perioperatif, mempertahankan SVR, kontrol PVR dan meminimalisir peningkatan konsumsi oksigen. ${ }^{2}$ Penting untuk diketahui berapa saturasi oksigen basal pada pasien dan apakah pasien pernah mengalami episode hypercyanotic tet spell, seberapa sering dan tingkat keparahan tiap episode dan bagaimana penanganannya. ${ }^{9}$ Halhal ini diperlukan untuk memperkirakan derajat keparahan PJB sianotik yang dialami pasien serta mempersiapkan langkah-langkah antisipasi untuk mengurangi kemungkinan terjadi hypercyanotic tet spell serta langkah-langkah yang dapat dilakukan untuk mengatasinya bila terjadi.

Secara umum, persiapan pasien sebelum pembedahan di antaranya adalah tetap memberikan medikasi yang telah diberikan sebelumnya, termasuk beta blocker pada pasien dengan TOF. Acetysalicylic acid (ASA) dosis rendah bukan merupakan kontraindikasi untuk pembedahan sederhana dan superfisial, namun bila pembedahan besar, termasuk intrakranial, perlu melakukan diskusi dengan ahli penyakit jantung dan ahli bedah dan umumnya ASA dihentikan 7-10 hari pra bedah pada pembedahan elektif. Dalam kondisi pasien akan dilakukan pembedahan, puasa prabedah dapat memperburuk gejala hiperviskositas dan meningkatkan risiko trombosis pada pembuluh darah otak. ${ }^{3}$ Pesanan puasa standar berlaku juga untuk populasi pasien dengan PJB termasuk cairan jernih sampai dengan 2 jam sebelum anestesia, ASI sampai dengan 4 jam sebelum anestesia, dan susu formula atau makanan padat sampai dengan 6 jam sebelum anestesia. Penting pada pasien dengan lesi sianotik, bergantung pintasan dan yang dengan obstruksi jalur keluaran untuk tidak dibiarkan puasa terlalu lama oleh karenanya hidrasi adekuat dengan cairan intravena harus dilakukan. Hipovolemia merupakan masalah kritis pada pasien ini terutama dengan induksi anestesia dan pemberian ventilasi tekanan positif. ${ }^{5}$ Pasien- pasien ini harus dijadwalkan di pagi hari dan bila terjadi penundaan maka pasien harus diberi cairan jernih sampai dengan 2 jam sebelum induksi. ${ }^{7}$ Tindakan pembedahan pada pasien ini bersifat darurat karena pasien mengalami kecelakaan. Pengelolaan pra bedah pada pasien ini meliputi survei prmier dan sekunder serta tindakan diagnostik memerlukan waktu 5 jam sejak pasien tiba di rumah sakit dan selama itu pula diberikan cairan rumatan berupa $\mathrm{NaCl} 0,9 \%$ sebanyak 500 $\mathrm{mL}$ agar pasien dalam kondisi normovolemia ketika dilakukan induksi anestesi.

Meskipun flebotomi sudah tidak rutin lagi dilakukan, flebotomi prabedah dapat membantu hemostasis terutama bila kadar hematokrit melebihi $65 \% .^{10}$ Jika diketahui terjadi defisiensi faktor pembekuan spesifik, dapat diberikan fresh frozen plasma (FFP) sebagai pengganti volume selama flebotomi pra bedah profilaksis. ${ }^{9}$ Pada pasien ini sejak dari awal penanganan karena sudah diketahui adanya PJB, selama menjalani diagnostik dan menunggu rencana pembedahan, diberikan suplementasi oksigen dan telah dipasang akses intravena serta diberikan cairan rumatan dengan harapan menjaga status hidrasi pasien agar tidak makin memperparah hiperviskositas yang kemungkinan sudah ada dengan kondisi kadar hemoglobin sebesar 20,5 g/ dL. Selain itu cairan rumatan diberikan dengan maksud untuk menjaga preload. Semua ini dilakukan agar optimalisasi hantaran oksigen ke otak tetap terjaga meskipun sudah dalam kondisi hipoksia kronis dan terjadi peningkatan tekanan intrakranial. Pada pengelolaan anestesi, premedikasi memegang peranan penting bagi pasien TOF. Rasa takut, cemas dan panik serta rangsangan simpatis lainnya akan memicu terjadinya hypercyanotic 'tet' spell. Midazolam adalah obat sedatif terpilih untuk menurunkan konsumsi oksigen. ${ }^{11}$

Premedikasi harus dilakukan dengan sangat hatihati karena dapat menyebabkan hipoventilasi dan hiperkarbi yang dapat meningkatkan resistensi pembuluh darah paru, khususnya pada pasien yang sudah mengalami hipertensi pulmonal sebelumnya atau pintasan sistemik ke pulmonal. Namun demikian, pasien dengan hipoksemia 
kronis tetap memiliki respons ventilasi normal terhadap hiperkarbia, sebaik terhadap analgesik opioid. ${ }^{3}$ Selama pembedahan, monitor non invasif standar seperti pulse oximetry, EKG, tekanan darah, kapnograf dan temperatur dipergunakan untuk semua pasien. Pulse oximetry dalam hal ini sangat penting pada pengelolaan pasien dengan PJB. Pada pasien dengan pintasan kanan ke kiri seperti pada pasien ini, penurunan saturasi arteri dapat berarti peningkatan pintasan kanan ke kiri. Sedangkan kadar karbondioksida pada akhir tidal dapat memberikan nilai estimasi yang lebih rendah untuk nilai $\mathrm{PaCO}_{2}$ dalam kasus pintasan kanan ke kiri3 dan besarnya perbedaan ini akan berubah sesuai dengan perubahan derajat pintasan. $^{2}$

Belum ada rekomendasi berbasis bukti untuk memandu pengelolaan pasien dengan PJB yang menjalani pembedahan non-jantung. Namun demikian, tujuan utama pengelolaan selama pembedahan adalah untuk memperbaiki hantaran oksigen ke jaringan dengan mencegah desaturasi arteri, mempertahankan keseimbangan antara aliran paru dan sistemik dan mengoptimalisasi hematokrit. ${ }^{3}$ Selain itu, penting untuk mencegah terjadinya takikardia dan hipovolemia selama pembedahan. ${ }^{5}$ Efek hipoksia kronis pada jantung adalah terjadi disfungsi miokard yang umumnya bermanifestasi sebagai penurunan compliance diastolik ventrikel dan penurunan cadangan miokard. Keterbatasan cardiac output mungkin tidak tampak pada saat istirahat, tetapi sering terjadi limitasi pada saat pasien beraktivitas lebih berat. ${ }^{2}$ Sebagian besar obat anestesi intravena menekan kontraktilitas miokard dan menurunkan resistensi pembuluh darah sistemik dan hal ini dapat menyebabkan efek yang tidak diinginkan pada hantaran oksigen pada jaringan selama induksi. Etomidate merupakan obat anestesi intravena terpilih karena stabilitas hemodinamik tetap terjaga pada pasien $\mathrm{PJB},{ }^{3}$ serupa dengan kondisi jantung terganggu lainnya. Namun demikian sebenarnya semua obat induksi intravena yang sering digunakan, aman digunakan pada pasien ini dengan catatan kecepatan dan dosis pemberian lebih menentukan ketimbang jenis obat yang diberikan, dan bila terdapat pintasan kanan ke kiri, hal ini akan meningkat. Sedangkan efek pintasan kanan ke kiri terhadap obat inhalasi umumnya adalah terjadi penundaan ambilan, namun demikian umumnya tidak menimbulkan masalah, meskipun induksi inhalasi pada pasienpasien ini umumnya memanjang. ${ }^{13}$ Pada pasien ini dilakukan induksi dengan teknik titrasi dengan memberikan thiopental secara bertahap sampai dengan tercapai dosis induksi $3 \mathrm{mg} / \mathrm{kg}$ berat badan. Namun demikian penurunan tekanan darah tetap terjadi sehingga kemungkinan pasien ini pun telah mengalami gangguan yang signifikan pada fungsi miokard.

Selama pembedahan diberikan norepinephrine secara kontinu untuk menjaga SVR. Analgetik, kedalaman anestesia, hemoglobin dan volume dipertahankan adekuat selama anestesi dan pembedahan sehingga tidak terjadi peningkatan kebutuhan oksigen dan peningkatan pelepasan katekolamin yang dapat memicu terjadinya tet spell. Pada pasien dengan TOF sudah terjadi hipoksemia kronis dengan dua mekanisme sekaligus yaitu aliran darah paru yang inadekuat dan/atau percampuran darah teroksigenasi dan terdeoksigenasi pada sirkulasi sistemik. ${ }^{11}$ Pengelolaan anestesi untuk pasien dengan aliran darah paru terbatas diantaranya hidrasi adekuat, minimalisir tahanan pada aliran darah paru dan mencegah peningkatan tiba-tiba akan kebutuhan oksigen (menangis, meronta dan tingkat anesthesia yang tidak adekuat).

Ada tidaknya pintasan penting untuk pengelolaan anestesi. Semua jalur intravena harus bebas dari gelembung udara dan apabila memungkinkan dilengkapi dengan filter ${ }^{10}$ untuk menurunkan risiko terjadinya embolisasi udara sistemik pada pasien dengan pintasan intrakardiak. Aliran darah melalui pintasan bergantung pada diameter defek dan keseimbangan antara tahanan pembuluh darah sistemik (SVR) dan pulmonal (PVR). Keseimbangan antara SVR dan PVR penting untuk pengelolaan anestesi pasien dengan pintasan. Pintasan intrakardiak memperpanjang induksi inhalasi, sedangkan induksi IV lebih cepat. Pintasan kanan ke kiri (seperti pada pasien TOF ini) atau pintasan terbalik terjadi ketika terjadi penurunan SVR dan peningkatan PVR. ${ }^{10}$ Peningkatan pintasan kanan ke kiri menyebabkan 
penurunan $\mathrm{SaO}_{2}$ yang tidak akan berespon dengan meningkatkan konsentrasi oksigen inspirasi. Ventilasi dead space akan meningkat karena penurunkan aliran darah pulmonal. Hypercyanotic spell selama anesthesia akan berespons terhadap pemberian oksigen, volume untuk meningkatkan stroke volume ventrikel kanan, tingkatkan kedalaman anestesi tanpa menurunkan tekanan darah arteri, sering dengan opioid seperti fentanyl untuk menurunkan pelepasan katekolamin, peningkatan SVR dengan agonis alfa seperti fenilefrin misalnya dan penurunan obstruksi jalur keluar ventrikel kanan dengan beta bloker. ${ }^{11}$ Penggunaan nitrous oxide harus dihindari karena selain meningkatkan PVR juga meningkatkan kemungkinan terjadinya emboli udara.

Hampir $20 \%$ pasien sianosis dengan eritrositosis mengalami gangguan hemostatik. ${ }^{9}$ Kecenderungan mengalami perdarahan dapat ringan dan superfisial, menyebabkan mudah lebam, ptechiae pada kulit dan perdarahan mukosa atau dapat sedang atau mengancam jiwa dengan epistaksis, hemoptisis atau perdarahan pascabedah. ${ }^{9}$ Gangguan hemostasis yang terjadi pada pasien sianosis merupakan sekunder karena ketidaknormalan jumlah dan fungsi trombosit, selain itu juga abnormalitas pada sistem koagulasi. Trombositopenia terjadi sekunder karena memendeknya usia trombosit karena penggunaan perifer. Sedangkan abnormalitas jalur koagulasi lebih sedikit diketahui penyebabnya, namun demikian bisa jadi karena berkurangnya serum karena polisitemia yang terjadi. Pasien dengan sianosis berat memiliki kadar faktor pembekuan bergantung vitamin $\mathrm{K}$, faktor $\mathrm{V}$ dan faktor von Willebrand yang sedikit. Hal ini menyebabkan meningkatnya International Normalized Ratio (INR) dan pemanjangan activated partial thromboplastin time (aPTT). ${ }^{3}$ Bagaimanapun, waktu pembekuan mungkin tidak meningkat, kemungkinan sekunder karena peningkatan viskositas darah dan penurunan aliran. Meskipun flebotomi sudah tidak rutin lagi dilakukan, flebotomi pra bedah untuk membantu hemostasis bedah mungkin berguna bila kadar hematokrit melebihi $65 \% .{ }^{10}$ Bila diketahui terjadi defisiensi faktor pembekuan spesifik, dapat diberikan fresh frozen plasma (FFP) sebagai pengganti volume selama flebotomi pra bedah profilaksis. ${ }^{9}$

Selain itu, peningkatan viskositas darah meningkatkan regangan pada pembuluh darah sehingga terjadi pelepasan prostaglandin dan endothelium-derived nictric oxide sehingga hasil akhirnya adalah dilatasi arteriol dan peningkatan vaskularisasi jaringan. ${ }^{3}$ Dua hal yang terakhir ini ikut berperan terhadap risiko perdarahan. Penggantian faktor koagulasi dan trombosit harus dipikirkan pada pasien yang menjalani pembedahan sedang atau berat. Heparin, warfarin dan asam asetilsalisilat harus dihindari kecuali merupakan indikasi untuk fibrilasi atrium yang persisten, adanya katup prostetik mekanik, trombosis vena dalam atau emboli paru. Obat anti inflamasi non steroid harus dihindari untuk mencegah kejadian perdarahan. ${ }^{9}$ Pemeriksaan laboratorium pada pasien ini didapatkan kadar trombosit yang masih dalam batas normal dengan faal hemostasis sedikit memanjang. Secara klinis selama pembedahan pasien mengalami perdarahan sebanyak 200 $\mathrm{mL}$, selain itu terdapat bekuan darah sebesar kurang lebih $50 \mathrm{~mL}$. Meskipun terkesan tidak banyak perdarahan yang terjadi namun kewaspadaan terhadap terjadinya perdarahan pascabedah masih harus terus dijaga. Analgesia pascabedah yang baik dan menghindari aktivasi sistem saraf simpatis dengan konsekuensi pelepasan katekolamin perlu ditimbang dengan efek penurunan SVR yang mungkin terjadi. ${ }^{2}$ Keseimbangan cairan penting pada pasien-pasien ini. Keputusan untuk melakukan ekstubasi pada akhir prosedur harus memperhitungkan tingkat keparahan dan patofisiologi yang mendasari, dan besarnya prosedur pembedahan. ${ }^{7}$ Pasien sebaiknya segera dikembalikan pada kondisi ventilasi spontan pada periode pascabedah. ${ }^{11}$

\section{Simpulan}

Keberhasilan penanganan pasien cedera otak traumatika dengan PJB sianotik ini tidak lepas dari pentingnya peranan ahli anestesi dalam memahami patofisiologi PJB sianotik dan teknik neuroanestesi sebab pasien-pasien ini sangat berisiko mengalami kondisi yang fatal terkait 
kondisi jantungnya. Namun demikian, dengan yang tidak kalah penting adalah kualitas hidup pasien setelah cedera otak traumatika terkait gejala sisa yang mungkin ada. Hal penting dalam penanganan pasien ini adalah optimalisasi hantaran oksigen ke otak yang mungkin terganggu karena kondisi hipoksia kronis akibat PJB sianotik serta aliran darah yang cenderung lambat karena adanya hiperviskositas akibat polisitemia. Selain itu, penting untuk mencegah terjadinya peningkatan kebutuhan oksigen dan pelepasan katekolamin yang dapat memicu terjadinya tet spell pada periode perioperatif.

\section{Daftar Pustaka}

1. Perloff JK, Warnes CA. Challenges posed by adults with repaired congenital heart disease. Circulation 2001;103:2637-2643.

2. Lovell AT. Anaesthetic implications of grown-up congenital heart disease. $\mathrm{Br} \mathrm{J}$ Anaesth 2004;93:129-139.

3. Canneson M, Earing MG, Collange V, Kersten JR. Anaesthesia for noncardiac surgery in adults with congenital heart disease. Anesthesiology 2009;111(2):43240.

4. Prajwal PHS, Rashmi HD, Devi U, Balasubramanyam M, Prabhu A. Anesthestic management of an adult patient with uncorrected ventricular septal defect posted for open cholecystectomy. International Journal of Medical Science and Public Health 2015;4(7):1023-1026.

5. Betranou EG, Blackstone EH, Hazelrig IB, Turner Jr. ME, Kirklin JW. Life expectancy without surgery in Tetralogy of Fallot. Am J Cardiol 1978; 42: 458-466.

6. Hennerin HA, Mendeloff EN, Cilley RE, Bove EL, Coran AG. Predictors of postoperative outcome after general surgical procedures in patients with congenital heart
Disease. J Pediatr Surg 1994;29(7):866-870.

7. Andropoulos DB. Anesthesia for the patient with congenital heart disease for noncardiac surgery. Anesthesiology 2011: American Society of Anesthesiologists Meeting;206:1-10.

8. Kyo S, Imanaka K, Masuda M, Miyata $\mathrm{T}$, Morita K, Morota T, dkk. Guidelines for perioperative cardiovascular evaluation and management for noncardiac surgery (JCS 2014). Circ J 2017;81:245-267.

9. Warnes CA, Williams RG, Bashore TM, Child JS, Connolly HM, Dearani JA, dkk. ACC/AHA 2008 Guidelines for the Management of Adults with Congenital Heart Disease: A Report of the American College of Cardiology/American Heart Association Task Force on Practice Guidelines (Writing Committee to Develop Guidelines on the Management of Adults with Congenital Heart Disease): Developed in Collaboration with the American Society of Echocardiography, Heart Rhythm Society, International Socitey for Adult Congenital Heart Disease, Society for Cardiovascular Angiography and Interventions, and Society of Thoracic Surgeons. Circulation 2008;118:e714-e833.

10. Khairy P, Poirier N, Mercier LA. Univentricular heart. Circulation 2007; 115:800-812.

11. Hamid M, Khan MA, Akhtar MI, Hameedullah, Saleemullah, Samad K, dkk. Grown up congenital heart disease patient presenting for non cardiac surgery: Anaesthetic implications. J Pak Med Assoc 2010;60(11): 955-959.

12. Wilson W, Taubert KA, Gewitz M, Lockhart PB, Baddour LM, Levison M, dkk. Prevention of infective endocarditis: Guidelines from the American Heart Association: A guideline from the American Heart Association Rheumatic Fever, Endocarditis, and Kawasaki Disease Committee, Council on 
Cardiovascular Disease in the Young, and the Council on Clinical Cardiology, Council on Cardiovascular Surgery and Anesthesia, and the Quality of Care and Outcomes Research Interdisciplinary Working Group. Circulation 2007;116:1736-1754.

13. Saurabh S, Neeraj K, Akhilesh SK, Amarjeet K, Subhdeep MWR. Perioperative management of uncorrected D-TGA with brain abscess: a case report. J Anesth Crit Care Open Access 2017;7(1):00251: 1-3.

14. Marsulasiddappa V, Raghavendra BS. Anesthesia for a rare case of uncorrected pentalogy of fallot undergoing craniotomy and drainage of brain abscess. J Clin Diagn Res 2015;9(7): UD01-UD02.

15. Kristensen SD, Knuuti J, Saraste A, Anker S, Botker HE, De Hert S, dkk. 2014 ESC/ ESA Guidelines on non-cardiac surgery: cardiovascular assessment and managemet: The Joint Task Force on non-cardiac surgery: cardiovascular assessment and management of the European Society of Cardiology (ESC) and the European Society of Anaesthesiology (ESA). Eur Heart J 2014; 1-50.

16. Brown ML, DiNardo JA, Nasr VG. Anesthesia in pediatric patients with congenital heart disease undergoing noncardiac surgery: defining the risk. J Cardiothorac Vasc Anesth 2019;00:1-9.

17. Bisri DY, Bisri T. Penatalaksanaan Anestesi untuk drainase abses otak pasien dengan Tetralogi of Fallot. JNI 2012;1(2):76-80.

18. Prasetya RJ, Umar N. Anestesi untuk drainase abses otak pada pasien dengan Tetralogy Fallot yang tidak dikoreksi. JNI 2013;2(1):22-28.

19. Suyasa AB, Umar N, Oetoro BJ. Implikasi anestesi pasien cedera kepala traumatik dengan penyakit jantung bawaan (PJB) sianotik: masalah hiperviskositas darah. JNI 2013;2(3):166-176. 